\title{
EXECUÇÃO DA PENA APÓS CONDENAÇÃO EM SEGUNDA INSTÂNCIA: CONSTITUCIONALISMO DISCURSIVO À BRASILEIRA
}

\section{Rafael Augusto Alves ${ }^{1}$}

Resumo: A partir dos julgamentos realizados pelo STF sobre a execução antecipada da pena a partir da condenação em segunda instância o presente artigo tem por objetivo estabelecer reflexões sobre o Constitucionalismo Discursivo e a sua capacidade de instituir a jurisdição constitucional como legítima mandatária popular a partir da representação argumentativa, conceito desenvolvido por Robert Alexy. Propomos a seguinte indagação: O concreto manejo deste aparato teórico nesta questão contribuiu para reforçar a legitimidade popular de nossa Suprema Corte enquanto intérprete da constituição?

Palavras-chave: Execução Antecipada. Pena. Presunção de Inocência. Constitucionalismo Discursivo

\section{EARLY EXECUTION OF THE PENALTY: BRAZILIAN DISCURSIVE CONSTITUCIONALISM.}

\begin{abstract}
From the judgments made by the Supreme Court on the early execution of the sentence (from the conviction in the second instance) this article aims to establish reflections on Discursive Constitutionalism and its ability to establish constitutional jurisdiction as legitimate popular mandate from of argumentative representation, concept developed by Robert Alexy. We propose the following question: Did the concrete handling of this theoretical apparatus in this question contribute to reinforce the popular legitimacy of our Supreme Court as interpreter of the constitution?
\end{abstract}

Keywords: Early Execution. Penalty. presumption of innocence Discursive Constitutionalism

\section{INTRODUÇÃO}

$\mathrm{O}$ exercício do judicial review em questões de grande sensibilidade social (hard cases) propicia o exame da eficácia e eficiência dos modelos teórico-dogmáticos do constitucionalismo moderno enquanto instrumentos de previsibilidade das decisões judiciais, estabilidade das relações institucionais e consolidação do respeito aos direitos fundamentais da Constituição. Nosso Supremo Tribunal Federal é um permanente "laboratório" de jurisdição constitucional. Infelizmente, não raras vezes, o concreto manejo da "alquimia

\footnotetext{
${ }^{1}$ Mestrando em Direito e Políticas Públicas do Centro Universitário de Brasília - Uniceub. Especialista em Sistemas de Justiça Criminal pela Universidade Federal de Santa Catarina. Especialista em Direito Econômico e das Empresas pela Fundação Getúlio Vargas. Procurador do Distrito Federal e Advogado. Email: rafaelaugustoalvesadv@gmail.com.
} 
constitucional" por nossa Suprema Corte incorre em resultado invertido, caracterizado pela desconfiança daqueles observadores que acompanham o respectivo fenômeno.

A discussão constitucional envolvendo a extensão do princípio da não culpabilidade ou da presunção de inocência (art. $5^{\circ}$, LVII da Constituição Federal) em relação à execução antecipada da pena (a partir da condenação em segunda instância) é caso emblemático neste sentido. Os últimos dez anos de debates sobre o tema nos oferece pródiga narrativa quanto aos desencontros vividos entre a jurisdição constitucional, legitimação democrática e rigor científico.

A partir do exame das manifestações do Supremo Tribunal Federal no caso acima referenciado, o presente artigo tem por objetivo estabelecer reflexões sobre o Constitucionalismo Discursivo e a sua capacidade de instituir a jurisdição constitucional como legítima mandatária popular, a partir da representação argumentativa, conceito desenvolvido por Robert Alexy. Em outras palavras, propomos a seguinte indagação: $\mathrm{O}$ concreto manejo deste aparato teórico no recorte ora proposto contribuiu para reforçar a legitimidade popular de nossa Suprema Corte enquanto intérprete da constituição?

\section{BREVÍSSIMA CONTEXTUALIZAÇÃO DO PRINCÍPIO.}

O princípio da não culpabilidade, do estado de inocência ou simplesmente princípio da "presunção de inocência" está positivado no rol de direitos e garantias fundamentais do indivíduo, especificamente no art. $5^{\circ}$, LVII, estabelecendo o seguinte preceito: Ninguém será considerado culpado até o trânsito em julgado de sentença penal condenatória. Previsão semelhante consta do art. $9^{\circ}$ da Declaração dos Direitos do Homem de $1789^{2}$ e art.11 da Declaração das Nações Unidas em $1948^{3}$.Guilherme Madeira Dezem(2008) registra interessante abordagem do princípio feita por Alberto Binder, enfocando-o sob o ponto de vista negativo:

\footnotetext{
${ }^{2}$ Artigo $9^{\circ}$ Todo acusado é considerado inocente até ser declarado culpado e, se julgar indispensável prendê-lo, todo o rigor desnecessário à guarda da sua pessoa deverá ser severamente reprimido pela lei.

${ }^{3}$ Artigo 11. Toda a pessoa acusada de um acto delituoso presume-se inocente até que a sua culpabilidade fique legalmente provada no decurso de um processo público em que todas as garantias necessárias de defesa lhe sejam asseguradas.
} 
Do ponto de vista prático, tais concepções modernas sobre presunção de inocência foram muito bem resumidas por Alberto Binder que, embora a conceitue o princípio de maneira negativa, assim afirma:"(...) fica mais claro conservar a formulação negativa para compreender seu significado; e o primeiro que esta formulação mostra é que 'ninguém é culpado se uma sentença não o declara assim'. Isto, de fato, significa que: 1 . Que somente a sentença tem essa faculdade; 2. Que no momento da sentença existem somente duas possibilidades: culpado ou inocente. Não existe uma terceira possibilidade; 3. Que a 'culpabilidade' deve ser juridicamente provada; 4. Que essa construção implica a aquisição de um grau de certeza; 5. Que o acusado não tem que provar sua inocência; 6 . Que o acusado não pode ser tratado como um culpado; 7. Que não podem existir mitos de culpa, isto é, partes da culpa que não necessitam ser provadas."

O princípio da presunção de inocência pode visto a partir de múltiplas perspectivas. Gustavo Badaró(2017) ressalta-o como garantia política, ao destacar que o mesmo se apresenta como fundamento sistemático e estrutural do processo acusatório, componente basilar de modelo processual penal comprometido com os direitos essenciais da pessoa humana. Aury Lopes Júnior (2016, p.182) observa que o princípio institui um dever de tratamento em relação ao réu, projetando-o em duas dimensões distintas.

A primeira delas repercute internamente ao processo e tem como destinatários as partes, e principalmente, o juiz da causa. Se por definição toda pessoa é inocente (até a sentença condenatória definitiva), então a condição de culpado deve ser suficientemente demonstrada por aquele que pretende impor qualquer consequência penal a outrem. Noutras palavras, a obrigação de provar a existência de infração penal e sua autoria é inteiramente do acusador. Estabelece-se, portanto, regra fundamental de distribuição do ônus da prova no processo penal.

A partir do mesmo raciocínio, outra consequência de natureza processual se revela, porém, configurada como critério ou regra de julgamento para o magistrado no momento de decidir a causa. Surgindo o estado de dúvida invencível ao julgador sobre a existência do fato processado, sua ilicitude, ou mesmo sua autoria, este impasse deve ser considerado em favor do acusado, resultando na sua absolvição. Ainda no tocante à perspectiva intraprocessual, o princípio coíbe o uso abusivo da prisão processual ou cautelar como instrumento de antecipação da resposta penal definitiva. Aliás, este específico ponto da questão será justamente o cerne do presente artigo, quando do exame dos julgamentos proferidos pela Suprema Corte. 
Sobre a dimensão externa do princípio, esta refere-se àqueles que não protagonizam a relação processual penal, voltando-se contra a publicidade abusiva e estigmatização do réu durante o transcorrer da marcha processual em respeito aos seus direitos fundamentais de imagem, dignidade e privacidade.

\title{
3.RETROSPECTO DOS PRINCIPAIS JULGAMENTOS ENVOLVENDO A EXECUÇÃO ANTECIPADA DA PENA NO SUPREMO TRIBUNAL FEDERAL.
}

A questão envolvendo a execução antecipada da pena e a sua compatibilidade com o princípio constitucional da presunção de inocência há tempos ocupa os escaninhos de nossa Suprema Corte:

\begin{abstract}
Antes de 1988, o Supremo Tribunal Federal decidia, a exemplo do que ocorreu no HC 59.7573, pela incompatibilidade do efeito suspensivo com o recurso extraordinário, sendo que, se o acusado tivesse sido condenado e preso, o recurso excepcional não impediria o início do cumprimento da pena. Mesmo após a entrada em vigor da Constituição Federal de 1988, no julgamento do HC 67.8574, o Pretório Excelso não via incompatibilidade entre o princípio da presunção de inocência e a execução provisória da pena. Em 1995, em sede do HC 72.3665, o Supremo julgou a constitucionalidade do art. 594 do Código de Processo Penal brasileiro, estabelecendo que a necessidade de recolher-se à prisão para apelar não feria o princípio da presunção de inocência. Seguiram-se inúmeras decisões nesse sentido.
\end{abstract}

Antes que essas decisões se sedimentassem, outras surgiram contrariamente, como no julgamento dos HC's 85.2096 e 83.5927, nos quais a Corte Suprema proibia a execução da pena privativa de liberdade antes do trânsito em julgado da decisão condenatória. (BELINI, 2018)

O primeiro grande giro jurisprudencial aconteceu no julgamento do Habeas Corpus n. 84.078-7, impetrado no ano de 2004. O caso contemplava paciente condenado por tentativa de homicídio duplamente qualificada, havendo contra si mandado de prisão preventiva, expedido depois do julgamento de apelação. O processo ainda pendia de definição por conta de Recursos Especial e Extraordinário movidos pela defesa do réu. A impetração enfrentou acórdão do Superior Tribunal de Justiça que referendou o decreto prisional ao argumento de que o princípio constitucional da não-culpabilidade não inibia a constrição do status libertatis do réu com condenação confirmada em segundo grau, porquanto os Recursos Especial e Extraordinário são, em regra, desprovidos de efeito suspensivo. O processamento deste Habeas Corpus iniciou-se na primeira turma do Tribunal, na relatoria do Ministro Nelson Jobim, que deferiu liminar em favor do paciente para mantê-lo solto até o julgamento final do writ. 
Em outubro daquele mesmo ano, o processo é levado a julgamento sob a relatoria do Ministro Eros Grau que profere voto pela concessão da ordem, ao defender a prevalência material e temporal dos preceitos da Lei n. 7.210/84 (Lei de Execução Penal) - que exigem o trânsito em julgado para o início da execução penal - sobre o previsto no artigo 637 do Código de Processo Penal, que autorizava a execução provisória da sentença penal condenatória. O julgamento foi interrompido por pedido de vista do Ministro Carlos Britto.

Em nova assentada realizada no mês seguinte, por maioria de votos, a Primeira Turma resolve afetar o caso ao Pleno do Tribunal, que somente em abril de 2008 retoma o seu julgamento para concluí-lo em fevereiro de 2009 com a concessão da ordem ao paciente. O Supremo Tribunal Federal considerou inconstitucional a execução da pena antes do trânsito em julgado, ressaltando que a prisão antes do trânsito em julgado da condenação somente pode ser decretada a título cautelar.

Passados seis anos, em fevereiro de 2016, o pleno do Supremo Tribunal Federal julga o Habeas Corpus 126.292, relator Ministro Teori Zavascki, e, modifica seu entendimento anterior para afirmar que a execução da pena depois da segunda instância de julgamento não ofende o previsto no artigo $5^{\circ}$ inciso LVII da Constituição Federal.

Ao observar que nas instâncias ordinárias acontece o exaurimento da matéria fáticoprobatória (e sob este aspecto a própria fixação da responsabilidade criminal do acusado), o relator entende inteiramente justificável a relativização e até mesmo a própria inversão do princípio da presunção de inocência, nos termos do art. 637 do Código de Processo Penal e do art. 27, $\S 2^{\circ}$ da Lei 8.038/1990. Em reforço ao seu entendimento, o Ministro faz menção à aprovação da Lei da Ficha Limpa (Lei Complementar 135/2010), e, também a outros preceitos de direito comparado.

No mesmo ano de 2016, a composição plena da Suprema Corte se reencontraria outras duas vezes com a mesma questão. Em outubro foram julgadas as medidas cautelares nas Ações Declaratórias de Constitucionalidade 43 e 44, onde se postulou o reconhecimento da compatibilidade constitucional do art. 283 do Código de Processo Penal ${ }^{4}$ (redação dada pela Lei n. 12.403/2011). O Plenário do STF manteve o entendimento proferido meses antes,

\footnotetext{
${ }^{4}$ Art. 283.Ninguém poderá ser preso senão em flagrante delito ou por ordem escrita e fundamentada da autoridade judiciária competente, em decorrência de sentença condenatória transitada em julgado ou, no curso da investigação ou do processo, em virtude de prisão temporária ou prisão preventiva.
} 
indeferindo as cautelares pretendidas. Um mês depois, no bojo do Recurso Extraordinário com Agravo n. 964.246, o Plenário Virtual do STF reconheceu a repercussão geral da matéria, e, reafirmou a jurisprudência dominante pela tese do Tema 925: A execução provisória de acórdão penal condenatório proferido em grau recursal, ainda que sujeito a recurso especial ou extraordinário, não compromete o princípio constitucional da presunção de inocência afirmado pelo artigo $5^{\circ}$, inciso LVII, da Constituição Federal.

Em abril de 2018, o STF novamente enfrenta a temática no ruidoso julgamento do Habeas Corpus 152.752, de caráter preventivo, tendo por paciente Luís Inácio Lula da Silva. $\mathrm{Na}$ ação penal 5046512-94.2016.4.04.7000/PR o ex-presidente foi condenado à pena privativa de liberdade pelos crimes por corrupção passiva e lavagem de dinheiro, com sentença confirmada pelo Tribunal Regional Federal da $4^{\text {a }}$. Região. Discutiu-se no caso o verbete sumular n. 122 daquela Corte Federal $^{5}$, que autoriza o início da execução provisória da pena imposta ao réu depois de esgotada a jurisdição da segunda instância de julgamento, independentemente da eventual interposição de recurso especial ou extraordinário. A liminar postulada foi denegada pelo Plenário do Tribunal, por maioria mínima.

A orientação sumular acima referenciada dá ensejo ao ajuizamento de nova Ação Direta de Constitucionalidade, de número 54, onde o Partido Comunista do Brasil reapresenta pedido análogo àquele formulado nas Ações Diretas de Constitucionalidade 43 e 44, porém, com a indicação de fato alegadamente novo, qual seja, a aplicação automática da prisão antecipada por cortes inferiores depois do julgamento em segunda instância, a qual ao seu juízo, discrepa dos pronunciamentos anteriores da Excelsa Corte.

\section{EXAME DOS VOTOS PROFERIDOS.}

A partir dos votos, discursos e atitudes manifestadas nos julgamentos acima indicados, pretendemos observar pequeno recorte do concreto do exercício da jurisdição constitucional em assunto de grande sensibilidade social.

Sem prejuízo de seu inestimável valor científico e político, não queremos neste texto reeditar o etéreo debate entre constitucionalismo e democracia. Portanto, não é objeto de nossa preocupação indicar qual instituição é mais habilitada ou legitimada para mediar as grandes questões públicas do país (Supremo Tribunal ou Parlamento). De igual sorte, não

\footnotetext{
5 "Encerrada a jurisdição criminal de Segundo Grau, deve ter início a execução da pena imposta ao réu, independentemente da eventual interposição de recurso especial ou extraordinário"
} 
examinaremos com profundidade o (des)acerto do Tribunal sobre a tese de fundo, pois, semelhante tarefa demandaria considerável incursão nos domínios do processo penal, da criminologia e política criminal.

O texto pretende reconhecer as categorias conceituais que fundamentaram a tese até então prevalente (constitucionalidade da execução antecipada), para observar se sua aplicação concreta correspondeu às expectativas idealizadas pelo respectivo modelo teórico. A análise ora empreendida permitirá revisitarmos conceitos fundamentais do constitucionalismo discursivo, além de nos propiciar reflexões sobre a credibilidade da atuação de nossa Suprema Corte no caso.

Quando cotejamos os votos proferidos nos julgamentos realizados no HC 84.078-7 (no ano 2009), HC 126.292(em 2016) e ADC 43/44(em 2016) notamos que os debates ali instaurados se desenvolveram a partir do mesmo eixo hermenêutico.

Aqueles que se alinharam à constitucionalidade da execução antecipada da pena depois da decisão de segunda instância tiveram como fundamento básico a existência de colisão de princípios constitucionais, de direito fundamentais. O princípio da presunção de inocência foi posto em confronto os cânones constitucionais da efetividade do sistema de justiça e da vedação da proteção constitucional deficiente.

Isso pode ser visto do voto vencido do Ministro Menezes de Direito no HC 84.078-7 e do voto vencedor do Ministro Teori Zavascki no HC 126.292. Vejamos alguns de seus trechos que indicam tal argumentação:

\section{$[\ldots]$}

De fato, após o devido processo nas instâncias ordinárias, presente a circunstância de que os recursos extraordinário e especial não dispõem de efeito suspensivo, a execução provisória é conseqüência possível, que, sem dúvida, pode ser afastada por meio dos instrumentos próprios, incluído o habeas corpus. Entendo que negar-se essa conseqüência ao julgado final das instâncias ordinárias, considerando as próprias limitação dos apelos extremos e a natureza expressa de efeito apenas devolutivo, transforma a Suprema Corte em nova instância regular, não excepcional, o que, pelo menos na minha compreensão, não tem guarida no sistema constitucional brasileiro. Há aqui um correto balanceamento capaz de proteger os direitos dos réus e os direitos da sociedade, que também tem direito a uma eficiente proteção do estado. Deixar soltos os réus já condenados nas instâncias ordinárias estimula a impunidade e protege aqueles que podem contar com os custos da multiplicidade de recursos que nossa 
generosa legislação processual permite. (BRASIL, 2010) - Voto Ministro Menezes de Direito - Negritamos

Nesse quadro, cumpre ao Poder Judiciário e, sobretudo, ao Supremo Tribunal Federal, garantir que o processo - único meio de efetivação do jus puniendi estatal, resgate essa sua inafastável função institucional. A retomada da tradicional jurisprudência, de atribuir efeito apenas devolutivo aos recursos especial e extraordinário (como, aliás, está previsto em textos normativos) é, sob esse aspecto, mecanismo legítimo de harmonizar o princípio da presunção de inocência com o da efetividade da função jurisdicional do Estado. Não se mostra arbitrária, mas inteiramente justificável, a possibilidade de o julgador determinar o imediato início do cumprimento da pena, inclusive com restrição da liberdade do condenado, após firmada a responsabilidade criminal pelas instâncias ordinárias.(BRASIL, 2016) - Voto Ministro Teori Zavascki Negritamos.

Dircursos similiares podem ser encontrados nos votos dos Ministros Edson Fachin e Luis Roberto Barroso nas Ações Diretas de Constitucionalidade 43 e 44 que firmaram a interpretação constitucional vencedora sobre o preceito do art. 283 do Código de Processo Penal. Na realidade, o raciocínio empreendido pelos votos ora destacados remonta ao denominado constitucionalismo discursivo que tenta promover a institucionalização da razão prática a partir de cinco conceitos: direitos fundamentais, ponderação, discurso, jurisdição constitucional e representação. Robert Alexy é o principal representante desta linha de pensamento.

O ponto de partida de Alexy é o conceito de direito sob uma perspectiva não positivista, onde o fenômeno jurídico não se confina ao seu aspecto puramente existencial, compreendendo também uma pretensão de correção. Para o professor alemão da Universidade de Kiel, a correção moral na aplicação do direito é aspecto inarredável, de modo que

[...] a correção moral, ideia característica do pensamento de Alexy, se manifesta no mundo do Direito sob a forma de justiça. Em suas palavras textuais: "Quem afirma que algo é justo, afirma sempre, ao mesmo tempo, que é correto". Nessa linha, Alexy refuta a ideia de Kelsen de que "qualquer conteúdo pode ser direito", o que daria lugar à possibilidade de uma normatividade sem moralidade. Contra esta visão, contrapõe-se a célebre fórmula de Radbruch, que em versão abreviada é assim enunciada: "Injustiça extrema não é direito". Indo adiante, Alexy considera que extremamente injusto é tudo aquilo que vulnera os direitos humanos básicos. E este mínimo de justiça tem validade universal(BARROSO, 2019) 
Dito de outro modo, o lado fático e institucional do direito (representado por sua existência e eficácia) deve necessariamente se enlaçar com sua dimensão ideal (plasmada na correção). A pretensão de correção buscada pelo direito deve compreender três requisitos: (a) a afirmação da correção; (b)a esperança do reconhecimento da correção e (c)a garantia da fundamentabilidade. $\mathrm{O}$ veículo que promove a pretensa correção do direito é a prática argumentativa jurídica, conduzindo-o à racionalidade das suas decisões (ALEXY, 2011, p.19 $-40)$.

Alexy propõe uma teoria da argumentação jurídica, na qual procura conciliar as regras dos discursos práticos gerais de Habermas com as formas de argumentação de Chaïn Perelman. Num momento posterior, o autor promove a construção de métodos de argumentação jurídica especiais para tratar as questões de direitos fundamentais, especialmente diante dos casos de colisão de preceitos fundamentais (SIMONI, 2010) Nesse particular, a distinção entre regras e princípios é capital, indicando a necessidade de instituição de procedimento decisório diverso do subsuntivo.

Sobre a diferenciação entre regras e princípios, Alexy considera que princípios são normas que ordenam que algo seja realizado na maior medida possível, dentro das possibilidades jurídicas e fáticas existentes, razão pela qual são considerados mandamentos de otimização. Já as regras, ou são satisfeitas ou não são satisfeitas. Não há gradação. Cumpre-se a exigência ou não(ALEXY, 2006).

Por isso, a ponderação é apresentada como método de resolução de "casos difíceis", onde determinado princípio fundamental deve ceder para que outro mais forte possa prevalecer no específico caso a ser resolvido. Alexy sintetiza a regra da ponderação nos seguintes termos: Quanto mais é o grau de não cumprimento ou prejuízo de um princípio, tanto maior deve ser a importância do cumprimento do outro(ALEXY, 2011, p 155-165).

Luis Roberto Barroso(2004) resume a técnica da ponderação a partir de três momentos distintos. O primeiro deles se caracteriza pela identificação das normas relevantes para a solução do conflito, reunindo-se os diversos fundamentos jurídicos-normativos potencialmente aplicáveis ao caso em julgamento. Na sequência, selecionam-se os fatos relevantes e suas respectivas consequências. Por derradeiro, a partir da aplicação conjunta dos diferentes grupos de normas e fatos, procuram-se as soluções possíveis verificando qual dos direitos prepondera, sendo possível graduar a intensidade da solução escolhida. $O$ fio 
condutor deste processo intelectual é o princípio instrumental da proporcionalidade e razoabilidade.

No intuito de se demonstrar a objetividade de sua teoria, Alexy propõe uma fórmula matemática para se definir o peso concreto do princípio a ser ponderado (fórmula peso), estruturada a partir de quociente obtido entre a intensidade da intervenção do primeiro princípio sobre a importância do cumprimento do outro princípio envolvido, representadas numericamente por graus de relevância.

A sustentação da legitimidade democrática da jurisdição constitucional na teoria do constitucionalismo discursivo dá-se pelo conceito de representação argumentativa. Neste modelo, a noção desejável de democracia transcende aos modelos puramente decisionistas (fundados nos conceitos de eleições e de maioria), para abranger um modelo deliberativo, onde a argumentação é fator indispensável para a tomada das decisões públicas. A fusão destas realidades democráticas leva à conclusão de que ao lado do Parlamento (que exerce representação volitiva e argumentativa), os tribunais constitucionais também estariam dotados de representação popular, porém, sob uma perspectiva puramente argumentativa - de deliberação(ALEXY, 2011, p 155-165).

O pensamento de Alexy influencia fortemente o Supremo Tribunal Federal. A ponderação é largamente utilizada como instrumento de resolução de questões constitucionais. $\mathrm{O}$ crescente entrelaçamento entre direito e política nas questões envolvendo direitos fundamentais e a tessitura aberta de nossas normas constitucionais (conceitos e valores) são aspectos que favorecem este modo de decidir.

Importante dizer que este modelo teórico (ponderação, discurso e representação argumentativa) sofre qualificadas críticas. A descrença sobre sua autoproclamada função, a falta de objetividade do processo ponderativo (sobretudo em relação à atribuição inicial dos graus de relevância dos princípios ponderados) e a duvidosa legitimidade democrática das cortes constitucionais face aos limitados instrumentos de "accountability" de sua atuação e acesso são objeções recorrentes à representação argumentativa. Ao analisar os limites da argumentação judicial, Juliana Brina Corrêa Lima de Carvalho (2013) expõe seu ceticismo sobre o modelo da ponderação:

A ponderação de princípios, nos moldes propostos por Alexy, neutraliza a confrontação agonística e permanente entre diferentes interpretações 
possíveis (e irredutíveis entre si) em caso de colisão. A idéia de uma harmonização de interesses, por meio da otimização de um princípio e da preservação da essência do outro princípio colidente em determinado caso, camufla a existência de um antagonismo, mas não o elimina.

Diferentemente, tal idéia camufla o fato de que, em realidade, por meio de uma decisão supostamente ponderativa, há apenas a imposição de um princípio em detrimento do outro, em sua totalidade, hegemonicamente.

Princípios não são ponderados: ponderam-se razões fáticas e jurídicas para a escolha de um princípio. Não se otimizam princípios: escolhe-se entre um princípio e outro, aplicando um deles integralmente. A teoria da argumentação jurídica camufla, portanto, tal decisão hegemônica, por meio de um método de fornecimento de razões que justificaria a correção de tal decisão e lhe serviria de fonte de legitimidade.

No que toca à representação argumentativa, digna de registro a advertência de Jane dos Reis Gonçalves Pereira(2014) ao descrever sobre os ônus que defluem do Judiciário quando o mesmo se credencia como poder representativo popular.

A ideia de que o Judiciário tem feição representativa pode aprimorar a democracia constitucional se essa compreensão não tiver por consequência a leitura de que tal atributo opera como credencial para falar em nome da comunidade (um fator de legitimação genética), mas sim como predicado que evidencia um múnus democrático que tem como consectário o ônus de abertura e porosidade em relação às variadas forças sociais.

Nesse sentido, a representatividade do Judiciário pode ser compreendida como:

i)um ideal regulativo, de que o Judiciário deve ser aberto aos desacordos morais que emergem da sociedade, processualmente poroso e institucionalmente transparente;

ii)um fator de aferição de legitimação ex post, que permite qualificar a atuação da corte como mais legítima nos cenários em que sua permeabilidade às forcas sociais, especialmente as mais vulneráveis, tenha sido retrospectivamente demonstrada (grifamos e negritamos).

A partir da ideia de Häberle que defende o direito processual constitucional como parte do direito de participação democrática, Paulo Gustavo Gonet Branco(2008) reforça a crença de que "os procedimentos nas jurisdições constitucionais devem ser adequados para que sejam conferidas consequências práticas ao reconhecimento de que a interpretação constitucional, se tem o juiz constitucional o detentor da última palavra, não prescinde de muldividências dos cidadãos".

Voltando ao objeto de análise, observamos questionável manejo do modelo teórico discursivo pelos votos que se declararam a favor da constitucionalidade da execução 
antecipada. Embora o conflito de princípios tenha sido chancelado expressamente por estes julgadores, observa-se nítido desapego à solução tecnológica correspondente, qual seja, $a$ ponderação de princípios. Vejamos as observações de Renato Belini (2018) sobre alguns destes principais votos da corrente vencedora (pela viabilidade da execução antecipada):

O Ministro Teori Zavaski, em seus votos tanto no HC 126.292 quanto na ARE 964.246, apesar de deixar claro estar-se diante de uma colisão entre os princípios da presunção de inocência e da efetividade, não resolveu essa colisão a partir da teoria da ponderação, mas sim introduziu em um dos princípios (presunção de inocência) uma cláusula de excecão que eliminou o conflito, chegando a formular o enunciado:

[...] a execução provisória de acórdão penal condenatório proferido em grau de apelação, ainda que sujeito a recurso especial e extraordinário, não compromete o princípio constitucional da presunção de inocência. (Grifo original).

Ocorre que esse é um recurso vocacionado à solução de conflitos entre regras, conforme lição de Robert Alexy acima reproduzida, sendo irracional a sua utilização para solucionar colisão entre princípios. Trata-se de uma irracionalidade formal. ....

A mesma característica se extrai dos votos do Ministro Edson Fachin, tanto no HC 126.292 quanto no HC 152.752, posto que, apesar de vislumbrar potencial colisão entre os princípios da presunção de inocência e da efetividade, não resolveu o problema a partir da ponderação, mas sim optou por realizar uma interpretação sistemática, típica da solução de conflitos entre regras, eis a irracionalidade formal. Nesse caso, não chegou a formular um enunciado incluindo uma cláusula de exceção na presunção de inocência, de maneira que, de acordo com a doutrina alexyana, simplesmente invalidou o referido princípio. (Negritamos e sublinhamos).

O mesmo articulista aponta equívocos materiais em relação àqueles que aplicaram o processo de ponderação. Ao apontar inexatidões empíricas sobre determinados dados estatísticos relacionados ao caso (efetivo percentual de recursos de natureza extraordinária providos), e, também certos equívocos dogmáticos (quanto à preclusão em segundo grau de situações processuais que configurariam o juízo de condenação do réu), o autor argumenta que:

O alcance da racionalidade da ponderação não pode depender apenas da observância de sua estrutura formal e material. A simples atribuição de graus não é suficiente para a racionalidade da ponderação. É imprescindível a apresentação das razões, por meio da argumentaç̃o jurídica, o que estamos identificando como estrutura discursiva.

Como já discutido, a necessidade de atribuição de graus para a fórmula da escalação triádica coloca a exigência de que sejam apresentadas as razões 
que justifiquem a atribuição dos graus leve, médio e grave. Com isso, tem-se uma imbricação necessária entre a ponderação e a argumentação jurídica. Apenas será racional a ponderação que respeitar esses três aspectos: o formal, o material e o discursivo.

A crítica que se faz à ponderacão realizada nos julgamentos dos HC's 126.292, 152.752, ADC's 43 e 44 e ARE 964.246 é exatamente esta: foi tomada a partir do estabelecimento de relações de precedência com razões insuficientes, pois não superaram o crivo da argumentacão jurídica, de maneira que a atribuição dos graus (aliás, nem se deu de maneira expressa) revelou um mecanismo meramente intuitivo, subjetivo, sendo que essa falta de objetividade leva à irracionalidade. BELINI (2018) grifamos e negritamos

Percebe-se, assim, que os discursos veiculados nestes votos não se acomodaram perfeitamente ao sistema de regras de discurso idealizado por Alexy. Tal proceder prejudica sobremaneira a garantia de fundamentabilidade preconizada por este modelo teórico, impactando diretamente na racionalidade das decisões, e, em última analise, compromete a finalidade última do direito que é pretensão de sua correção, pedra de toque do constitucionalismo discursivo.

Por outro lado, outros comportamentos também depuseram contra a legitimação democrática do Supremo ao longo destes julgamentos. Em 1 de julho de 2016, poucos meses depois do julgamento do Habeas Corpus n. 126.292(onde o Pleno do Supremo Tribunal Federal já havia se declarado favorável à constitucionalidade da execução antecipada) o Ministro Celso de Mello concedeu liminar no Habeas Corpus n. 135.100 em sentido diametralmente oposto ao decidido pelo Tribunal. Na sua decisão, depois de reproduzir os mesmos argumentos vencidos naquela assentada plenária, o Ministro afirmou:

Nem se invoque, finalmente, o julgamento plenário do HC 126.292/SP - em que se entendeu possível, contra o meu voto e os de outros 03 (três) eminentes Juízes deste E. Tribunal, "a execução provisória de acórdão penal condenatório proferido em grau de apelação, ainda que sujeito a recurso especial ou extraordinário" -, pois tal decisão, é necessário enfatizar, pelo fato de haver sido proferida em processo de perfil eminentemente subjetivo, não se reveste de eficácia vinculante, considerado o que prescrevem o art. 102, $\& 20$, e o art. 103-A, "caput", da Constituicão da República, a significar, portanto, que aquele aresto, embora respeitabilíssimo, não se impõe à compulsória observância dos juízes e Tribunais em geral.(BRASIL, 2016 b).

A par da cartesiana correção do argumento processual lançado na decisão, este discurso não se coaduna com a racionalidade esperada naquele específico contexto, onde o Supremo Tribunal em sua composição plenária já havia definido a questão poucos meses 
atrás. Este precedente rompe com o dever de coerência que se espera de uma corte constitucional, provedora de racionalidade institucional.

A mesma reflexão pode ser aplicada à surpreendente decisão liminar proferida monocraticamente pelo Ministro Marco Aurélio na Ação Declaratória de Constitucionalidade 54 reconhecendo a compatibilidade constitucional do artigo 283 do Código de Processo Penal, mesmo diante do entendimento contrário firmado no julgamento das cautelares das Ações Declaratórias de Constitucionalidade 43 e 44. A decisão seria suspensa horas depois pelo presidente da Corte.

Interessante observar nesta decisão as abertas críticas da Relatoria sobre certos comportamentos institucionais no caso em concreto, relacionados à prática deliberativa da Corte. A questão envolvendo a definição da pauta para julgamento das ADCs 43 e 44 e as decisões proferidas no bojo de processos de caráter subjetivo em detrimento às ações objetivas(que já estariam aptas a julgamento) são circunstâncias relevantes, porque põem em dúvida a porosidade processual e a transparência institucional exigidas da Corte, se esta se coloca como ungida de representação popular argumentativa. Vejamos o trecho.

Na Sessão Plenária de 5 de outubro de 2016, a sempre ilustrada maioria concluiu pelo indeferimento das medidas acauteladoras postuladas nas mencionadas ações declaratórias de constitucionalidade, tendo ficado vencido na companhia dos ministros Rosa Weber, Ricardo Lewandowski, Celso de Mello e, em parte, Dias Toffoli - circunstância que, a princípio, afastaria a pertinência de novo exame colegiado de pedido de implemento de medida acauteladora.

Observada a ordem processual, em 4 de dezembro de 2017, liberei ambos os processos para insercão, visando o julgamento de mérito, na pauta dirigida do Pleno, ato situado no campo das atribuicões da Presidência.

Conforme aponta o requerente, sobreveio fato novo a respaldar, mesmo no campo precário e efêmero, nova manifestação deste Tribunal: os pronunciamentos dos integrantes do Supremo, por ocasião do exame do habeas corpus no 152.752, relator ministro Edson Fachin, encerrado na Sessão Plenária de 4 de abril de 2018. A votação por maioria simples de 6 votos no sentido do indeferimento da ordem não mais representaria a visão majoritária do Colegiado a respeito da constitucionalidade, em tese, do artigo 283 do Código de Processo Penal, considerada a evolução, no entendimento, do ministro Gilmar Mendes, e a ressalva da posição pessoal quanto ao tema realizada pela ministra Rosa Weber, no que, apesar de assentar a possibilidade de execução provisória da pena, no caso específico, aludindo à dita jurisprudência dominante do Supremo, ressaltou a necessidade de ser a questão revisitada quando da análise dos processos objetivos de minha relatoria. 
O quadro conduziu o Partido Ecológico Nacional - PEN, na ação declaratória de no 43 , a requerer nova apreciação da matéria. Liberei o pedido para julgamento do Pleno em 23 de abril de 2018, conforme despacho cuja cópia foi remetida à Presidência.

O fato de o Tribunal, no denominado Plenário Virtual, atropelando os processos objetivos acima referidos, sem declarar, porque não podia fazê-lo em tal campo, a inconstitucionalidade do artigo 283 do aludido Código, e, com isso, confirmando que os tempos são estranhos, haver, em agravo que não chegou a ser provido pelo relator, ministro Teori Zavascki - agravo em recurso extraordinário no 964.246, formalizado, por sinal, pelo paciente do habeas corpus no 126.292 -, a um só tempo, reconhecido a repercussão geral e "confirmado a jurisprudência", assentada em processo único - no citado habeas corpus -, não afasta a relevância da causa de pedir lançada na petição inicial, no que direcionada à preservação de garantia constitucional de envergadura maior, revelada em cláusula pétrea - conforme a qual "ninguém será considerado culpado até o trânsito em julgado de sentença penal condenatória" - inciso LVII do artigo 50 da Carta da República (BRASIL, 2019). Negritamos e Sublinhamos.

\section{CONCLUSÃO.}

Dentro dos limites deste trabalho, procuramos examinar a questão da legitimidade da jurisdição constitucional a partir da representação argumentativa de Alexy nos julgamentos envolvendo a execução antecipada da pena depois da segunda instância de julgamento.

A partir dos votos proferidos nos vários julgamentos envolvendo o tema, observamos questionável manejo do modelo discursivo, prejudicando a garantia de fundamentabilidade das decisões, o que coloca em suspeição a efetividade do constitucionalismo discursivo como instância mediadora entre jurisdição constitucional e democracia.

A pretensão de exercer a representação argumentativa exige dos membros do Tribunal compromisso de coerência de seus discursos e decisões com os modelos teóricos que alegam aplicar. Além disso, a institucionalidade da Corte deve propiciar a ampliação do acesso e participação de outros atores nas deliberações de jurisdição constitucional, além da efetivação instrumentos de controle sobre sua atuação jurisdicional, de modo a prevenir decisões e comportamentos que se constituam em meros atos de vontade do julgador.

\section{REFERENCIAS.}

ALEXY. Robert. Minha filosofia do Direito: a institucionalização da razão. Constitucionalismo Discursivo. 3a. Edição. 2001. Livraria do Advogado. p.19-40.

Teoria dos Direitos Fundamentais. Trad. de Virgílio Afonso da Silva da 5a Ed. alemã. Ed. Malheiros. São Paulo, 2006. 
Ponderação, jurisdição constitucional e representação. Constitucionalismo Discursivo. 3a. Edição. 2001. Livraria do Advogado. p.155-165.

BADARÓ, Gustavo Henrique. Processo Penal. 2017. Revista dos Tribunais. Capítulo 1, item 1.7. Biblioteca Thomson Reuters Proview.

BARROSO, Luis Roberto. Colisão entre Liberdade de Expressão e Direitos de Personalidade. Critérios de Ponderação. Interpretação. Constitucionalmente adequada do Código Civil e da Lei de Imprensa. Disponível em <http://www.migalhas.com.br/arquivo_artigo/art_03-10-01.htm> acessado em 30.07.18.

Grandes Transformações do Direito Contemporâneo e o pensamento de Robert Alexy. Disponível em <https://www.conjur.com.br/dl/palestra-barroso-alexy.pdf. $>$ Acesso em 14.03.19.

BELINI, Renato. Execução Provisória da Pena no Brasil: As irracionalidades da atual Jurisprudência do STF. Revista Brasileira de Ciências Criminais. vol. 145/2018.p. 281-318. jul/2018.

BRANCO. Paulo Gustavo Gonet. Juízo de Ponderação da Jurisdição Constitucional pressupostos de fato e teóricos reveladores de seu papel e de seus limites. 2008Disponível em <http://repositorio.unb.br/bitstream/10482/5128/1/2008_Paulo Gustavo Gonet Branco.pdf >.Acesso em 05.03.19.

BRASIL. Supremo Tribunal Federal. Acórdão no Habeas Corpus n. 84.078-7-MG. Relator: Eros Grau. HABEAS CORPUS. INCONSTITUCIONALIDADE DA CHAMADA "EXECUÇÃO ANTECIPADA DA PENA". ART. 5', LVII, DA CONSTITUIÇÃO DO BRASIL. DIGNIDADE DA PESSOA HUMANA. ART. $1^{\circ}$, III, DA CONSTITUIÇÃO DO BRASIL. 1. O art. 637 do CPP estabelece que "[o] recurso extraordinário não tem efeito suspensivo, e uma vez arrazoados pelo recorrido os autos do traslado, os originais baixarão à primeira instância para a execução da sentença". A Lei de Execução Penal condicionou a execução da pena privativa de liberdade ao trânsito em julgado da sentença condenatória. A Constituição do Brasil de 1988 definiu, em seu art. 5, inciso LVII, que "ninguém será considerado culpado até o trânsito em julgado de sentença penal condenatória". 2. Daí que os preceitos veiculados pela Lei n. 7.210/84, além de adequados à ordem constitucional vigente, sobrepõem-se, temporal e materialmente, ao disposto no art. 637 do CPP. 3. A prisão antes do trânsito em julgado da condenação somente pode ser decretada a título cautelar. 4. A ampla defesa, não se a pode visualizar de modo restrito. Engloba todas as fases processuais, inclusive as recursais de natureza extraordinária. Por isso a execução da sentença após o julgamento do recurso de apelação significa, também, restrição do direito de defesa, caracterizando desequilíbrio entre a pretensão estatal de aplicar a pena e o direito, do acusado, de elidir essa pretensão. 5. Prisão temporária, restrição dos efeitos da interposição de recursos em matéria penal e punição exemplar, sem qualquer contemplação, nos "crimes hediondos" exprimem muito bem o sentimento que EVANDRO LINS sintetizou na seguinte assertiva: "Na realidade, quem está desejando punir demais, no fundo, no fundo, está querendo fazer o mal, se equipara um pouco ao próprio delinqüente". 6. A antecipação da execução penal, ademais de incompatível com o texto da Constituição, apenas poderia ser justificada em nome da conveniência dos magistrados --- não do processo penal. A prestigiar-se o princípio constitucional, dizem, os tribunais [leia-se STJ e STF] serão inundados por recursos especiais e extraordinários e subseqüentes agravos e embargos, além do que "ninguém mais será preso". Eis o que poderia ser apontado como incitação à "jurisprudência defensiva", que, no extremo, 
reduz a amplitude ou mesmo amputa garantias constitucionais. A comodidade, a melhor operacionalidade de funcionamento do STF não pode ser lograda a esse preço. 7. No RE 482.006, relator o Ministro Lewandowski, quando foi debatida a constitucionalidade de preceito de lei estadual mineira que impõe a redução de vencimentos de servidores públicos afastados de suas funções por responderem a processo penal em razão da suposta prática de crime funcional [art. $2^{\circ}$ da Lei n. 2.364/61, que deu nova redação à Lei n. 869/52], o STF afirmou, por unanimidade, que o preceito implica flagrante violação do disposto no inciso LVII do art. $5^{\circ}$ da Constituição do Brasil. Isso porque --- disse o relator --- "a se admitir a redução da remuneração dos servidores em tais hipóteses, estar-se-ia validando verdadeira antecipação de pena, sem que esta tenha sido precedida do devido processo legal, e antes mesmo de qualquer condenação, nada importando que haja previsão de devolução das diferenças, em caso de absolvição". Daí porque a Corte decidiu, por unanimidade, sonoramente, no sentido do não recebimento do preceito da lei estadual pela Constituição de 1.988, afirmando de modo unânime a impossibilidade de antecipação de qualquer efeito afeto à propriedade anteriormente ao seu trânsito em julgado. A Corte que vigorosamente prestigia o disposto no preceito constitucional em nome da garantia da propriedade não a deve negar quando se trate da garantia da liberdade, mesmo porque a propriedade tem mais a ver com as elites; a ameaça às liberdades alcança de modo efetivo as classes subalternas. 8. Nas democracias mesmo os criminosos são sujeitos de direitos. Não perdem essa qualidade, para se transformarem em objetos processuais. São pessoas, inseridas entre aquelas beneficiadas pela afirmação constitucional da sua dignidade (art. $1^{\circ}$, III, da Constituição do Brasil). É inadmissível a sua exclusão social, sem que sejam consideradas, em quaisquer circunstâncias, as singularidades de cada infração penal, o que somente se pode apurar plenamente quando transitada em julgado a condenação de cada qual Ordem concedida. 2.010-Publicado no DJ 26-02-2010.

Disponível

em $<$ http://redir.stf.jus.br/paginadorpub/paginador.jsp?docTP=AC\&docID=608531 >Acessado em 14-03-2019.

Supremo Tribunal Federal. Acórdão no Habeas Corpus n. 126.292-SP. Relator: Teori Zavascki. CONSTITUCIONAL. HABEAS CORPUS. PRINCÍPIO CONSTITUCIONAL DA PRESUNÇÃO DE INOCÊNCIA (CF, ART. 5', LVII). SENTENÇA PENAL CONDENATÓRIA CONFIRMADA POR TRIBUNAL DE SEGUNDO GRAU DE JURISDIÇÃO. EXECUÇÃO PROVISÓRIA. POSSIBILIDADE. 1. A execução provisória de acórdão penal condenatório proferido em grau de apelação, ainda que sujeito a recurso especial ou extraordinário, não compromete o princípio constitucional da presunção de inocência afirmado pelo artigo $5^{\circ}$, inciso LVII da Constituição Federal. 2. Habeas corpus denegado.2016 - Publicado no DJE 17/05/2016 - Ata no 71/2016. DJE no 100, divulgado em 16/05/2016. Disponível em <http : // redir . stf . jus . br / paginadorpub / paginador.jsp ? docTP $=$ TP \& doc ID = 10964246> Acessado em 14-03-2019.

Supremo Tribunal Federal. Decisão Interlocutória no Habeas Corpus n. 135.100-MG. Relator: Celso de Mello. EMENTA: "HABEAS CORPUS". CONDENAÇÃO PENAL. HOMICÍDIO QUALIFICADO (CP, ART. 121, § 2, INCISOS I E IV). CRIME HEDIONDO. TRÂNSITO EM JULGADO PARA O MINISTÉRIO PÚBLICO. RECURSO EXCLUSIVO DO RÉU. "REFORMATIO IN PEJUS". VEDAÇÃO (CPP, ART. 617, “in fine").DECRETAÇÃO, "ex officio”, DE PRISÃO. EXECUÇÃO PROVISÓRIA DA PENA ("CARCER AD POENAM"). INADMISSIBILIDADE. AFIRMAÇÃO, PELO TRIBUNAL DE JUSTIÇA LOCAL, DE QUE A CONDENAÇÃO CRIMINAL EM PRIMEIRA INSTÂNCIA, NÃO OBSTANTE AINDA RECORRÍVEL, AFASTA A PRESUNÇÃO DE 
INOCÊNCIA E FAZ PREVALECER A PRESUNÇÃO DE CULPABILIDADE DO RÉU (VOTO DO DESEMBARGADOR REVISOR). INVERSÃO INACEITÁVEL QUE OFENDE E SUBVERTE A FÓRMULA DA LIBERDADE, QUE CONSAGRA, COMO DIREITO FUNDAMENTAL DE QUALQUER PESSOA, A PRESUNÇÃO CONSTITUCIONAL DE INOCÊNCIA. PRERROGATIVA ESSENCIAL QUE SOMENTE SE DESCARACTERIZA COM O TRÂNSITO EM JULGADO DA CONDENAÇÃO CRIMINAL (CF, ART. 5 ${ }^{\circ}$, INCISO LVII). CONSEQUENTE ILEGITIMIDADE CONSTITUCIONAL DA EXECUÇÃO PROVISÓRIA DA PENA. ENTENDIMENTO QUE IGUALMENTE DESRESPEITA A PRÓPRIA LEI DE EXECUÇÃO PENAL, QUE IMPÕE, PARA EFEITO DE APLICAÇÃO DAS PENAS PRIVATIVAS DE LIBERDADE E/OU RESTRITIVAS DE DIREITOS, O PRÉVIO TRÂNSITO EM JULGADO DO TÍTULO JUDICIAL CONDENATÓRIO (LEP, ARTS. 105 E 147). INAPLICABILIDADE, AO CASO, DO JULGAMENTO PLENÁRIO DO HC 126.292/SP: DECISÃO MAJORITÁRIA (7 VOTOS A 4) PROFERIDA EM PROCESSO DE PERFIL MERAMENTE SUBJETIVO, DESVESTIDA DE EFICÁCIA VINCULANTE (CF, ART. 102, § $2^{\circ}$, E ART. 103-A, "CAPUT"). PRECEDENTE QUE ATUA COMO REFERÊNCIA PARADIGMÁTICA, E NÃO COMO PAUTA VINCULANTE DE JULGAMENTOS. MEDIDA CAUTELAR DEFERIDA. 2016 - DJe-140 Div 04/07/2016 Public 01/08/2016. Disponível em < http://portal.stf.jus.br/processos/downloadPeca.asp?id=309868730\&ext=.pdf $>$ Acessado em 14-03-2019.

Supremo Tribunal Federal. Decisão Interlocutória na Ação Declaratória de Constitucionalidade 54. Medida Cautelar.Relator: Marco Aurélio. AÇÃO DECLARATÓRIA DE CONSTITUCIONALIDADE - MEDIDA ACAUTELADORA RELATOR - ATUAÇÃO - EXCEPCIONALIDADE VERIFICADA - DEFERIMENTO. 2019 julgado em 19/12/2018, publicado em PROCESSO ELETRÔNICO DJe-019 DIVULG 31/01/2019 PUBLIC 01/02/2019) Disponível em <http://stf.jus.br/portal/jurisprudencia/listarJurisprudencia.asp?s1=\%28ADC\%24\%2ESCLA \% 2E+E+54\%2ENUME\%2E\%29+NAO+S\%2EPRES\%2E\&base=baseMonocraticas\&url=http:/ /tinyurl.com/y3apsv62> Acesso 14-03-2019.

CARVALHO. Juliana Brina Corrêa Lima de. Sobre os Limites da Argumentação Judicial: Ativismo Judicial, Jürgen Habermas e Chantal Mouffe. Revista do Direito Público, Londrina, v.8, n.1, p.9-52, jan/abr 2013.

DEZEM. Guilherme Madeira. Presunção de Inocência: Efeito Suspensivo dos Recursos Extraordinários e Especial e Execução Provisória. Revista Brasileira de Ciências Criminais. vol. 70/2008. p. 269 - 290.Jan - Fev / 2008.

JUNIOR, Aury Lopes. Direito Processual Penal. Saraiva. 13a.Edição p.182.

PEREIRA. Jane Reis Gonçalves. Representação democrática do Judiciário: reflexões preliminares sobre os riscos e dilemas de uma ideia em ascensão. Disponível em <https:/ / www. academia.edu / 11309248/ Representação democrática_do_Judiciário_reflexões_preliminares_sobre_os_riscos_e_dilemas_de_uma_idei a_em_ascensão>. Acesso em 14.03.19.

SIMIONI. Rafael. Economia de colisões:ponderando a teoria da ponderação de Robert Alexy. Revista do Curso de Direito da FSG. Caxias do Sul ano 4 n.7 jan/jun. 2010 p. 135-150. 